\title{
IMPLEMENTING CONTENT AND LANGUAGE INTEGRATED LEARNING (CLIL) IN ESTONIA: SUBJECT AND LANGUAGE TEACHER PERSPECTIVE
}

\author{
Anna Dvorjaninova, Ene Alas
}

\begin{abstract}
The article discusses a study exploring teacher concerns related to implementing the Content and Language Integrated Learning (CLIL) approach to subject teaching, using English as the medium of instruction. Responses to a questionnaire study conducted among English and geography teachers reveal a reluctance to apply the approach in their own classrooms. The reason is the widespread belief that the approach benefits the development of language skills rather than subject knowledge advancement, marginalising the latter and thus undermining the overall achievement of curricular goals. Coupled with the English teachers' admitted lack of subject-specific content knowledge, the subject teachers' generally low estimate of their English language proficiency renders the prospect of incorporating the approach in the mainstream classrooms quite challenging. The latter is enhanced by the perceived lack of appropriate teaching materials, the temporal concerns related to developing a new course with accompanying materials and insufficient command of the respective methodology.*
\end{abstract}

Keywords: language learning and teaching, CLIL, subject and language teacher perceptions, curriculum development, language proficiency, subject advancement

\section{Introduction}

Content and Language Integrated Learning (CLIL) denotes an approach to teaching and learning a subject in a second or foreign language, usually involving a part of the whole subject curriculum (Ball et al. 2015: 10). It has assumed particular relevance in light of globalisation, striving to prepare students for 'mobility and internationalisation' (Dafouz, Guerrini 2009: 6) in their future professional and personal life.

* The authors of this article would like to thank the reviewers for a positive evaluation of the article and for 
Also, a noticeable increase in the immigrant population in the classrooms all over Europe and elsewhere warrants a common language of interaction for the successful teaching of the curriculum. Ball et al. (2015: 10) maintain that the former goal is usually a self-selected decision on the part of a school to offer students who mostly share a common first language a more meaningful context for foreign language learning and tends to be implemented by language teachers with some subject teacher support within a language curriculum. In the context of multicultural classrooms, however, where the students do not share a common first language, finding one for instruction arises out of necessity in most subject-specific classes. CLIL is then applied overwhelmingly by subject teachers to teach the subject curriculum with some language teacher support. The latter context - using English to teach a full subject curriculum because of the lack of a common language among students in the classroom - is currently rare in Estonian mainstream schools. According to the data received from the Estonian Ministry of Education and Research, there were 4 schools in Estonia in 2017 that offered a full curriculum in English with 60 students enrolled in those programmes. ${ }^{1}$ Teaching a subject or a part of its curriculum in English for the language development purposes is fairly widespread and has quite a long history (cf. Maljers 2007, Mehisto 2008 and Tampere 2010 for a detailed account of the spread of CLIL in Estonia).

With the influx of students representing a variety of languages non-indigenous to Estonia, there is an increased likelihood of both language and subject teachers having to address such classrooms in the foreseeable future, requiring a CLIL approach relying on English as the medium of instruction. According to previous research (Lin 2016), a CLIL teacher needs a specific disposition as well as a toolkit to teach the curriculum effectively.

With the above in mind, the research questions for the current study were formulated as follows:

- How prepared are subject teachers and English teachers to teach a subject in English?

- What do they perceive as challenges to the effective implementation of the CLIL approach?

Answers to the query were sought with the help of a survey conducted among Estonia's mainstream school English teachers and geography teachers, as the latter represent the subject most frequently chosen as the subject to be taught in English in Estonian schools and thus those teachers were expected to have the most experience in order to provide informed responses.

\section{Background to the study. CLIL teachers}

Although the advent of CLIL is dated to the mid-1990s in Europe, the idea of using a foreign language to teach a subject was practiced much earlier in Estonia. Some local schools have been using the concept, without calling it CLIL, since the 1950s and even earlier. In the 1960s, Tallinn School No. 7 (Tallinn English College) and Tallinn School No. 21 started teaching content subjects in a foreign language. Later, some schools in Tallinn, Tartu, Rapla, Võru and Rakvere developed a demanding 
curriculum for extensive English as well as German studies which involved teaching particular subjects in a foreign language. For example, Tallinn School No. 26 - a Russian-medium school - has been offering geography, literature and a subject generally referred to as 'regional studies' (focusing on the geography, history and culture of English-speaking countries) in English since 1966. Similarly, Tallinn Schools No. 7, 21, 42, 44 and Tartu School No. 2 (now Tartu Miina Härma Gymnasium) taught a number of subjects in a foreign language. The tradition has persisted to the point where, for example, Tallinn English College (formerly Tallinn School No. 7) is the first municipal school in Estonia to be granted the International Baccalaureate World School status which means that a full programme - the IB Diploma Program - is taught in English as of 2009. ${ }^{2}$ CLIL-related research literature approaches the phenomenon in a variety of ways, sometimes treating CLIL as an umbrella term covering immersion education, bilingual education, minority education or L2-medium subject teaching (cf. Mehisto 2008). Ball et al. (2015: 5-11) are adamant about CLIL being distinct from the aforementioned in that, unlike those forms of learning, CLIL involves only a few subjects of the curriculum, presupposes a certain level of L2 competence from the students when they enrol and requires strong cognitive academic language proficiency from them; it is usually highly valued by the parents and usually results in very good subject and language knowledge (Ball et al. 2015: 5-11). They distinguish between 'hard' CLIL, with a focus on subject content taught by subject teachers for the whole duration of the course; and 'soft' CLIL, affecting a part of the subject curriculum, highlighting its language aspect and involving language teachers in its delivery (Ball et al. 1-2). Both approaches set pedagogical and linguistic requirements for the teachers working in those contexts.

Integrated subject and language teaching/learning is shown in research literature (Ball et al. 2015, Dalton-Puffer, Nikula 2015, Genesee, Hamayan 2016) to have a number of advantages and come with a set of challenges. The advantages of the approach are substantial. Genesee and Hamayan (2016:57) note that the approach

- utilises first language learning abilities in learning the foreign language;

- exposes learners to authentic forms of language;

- builds on students' interest in learning a language for real communication in specific content areas;

- utilises socially and cognitively challenging learning activities for extensive interaction, fostering negotiation of meaning;

- ensures that language learning has value outside the classroom.

Yet, adopting the CLIL approach is not always easy. Stryker and Leaver (1993: 293) identify the CLIL teacher duties in the classroom as manifold: they should adopt an appropriate style of instruction in the classroom; make use of group work and cooperative learning strategies; identify students' prior linguistic knowledge and skills; help the student to develop strategies to cope with different situations, i.e. stimulate learner autonomy; use suitable techniques for error correction; develop and maintain high levels of student self-confidence. Coyle (2007) demonstrates that a CLIL teacher is working within a 4 C's framework, integrating subject content, communication, cognition and culture. Hurajová and Luprichová (2015: 101) echo Marsh's (2009) requirement that in the CLIL environment 'the teachers of content should have sufficient linguistic competence to be able to pass on academic

Cf. https://tik.edu.ee (28.3.2018). 
content in a target language as well as an in-depth knowledge of their own subject', in addition to which a set of pedagogical strategies should be acquired to promote teacher-student and student-student interaction and learner autonomy. Given the complexity of the task, teachers are bound to face challenges on several levels. Pavón and Rubio (2010: 46), discussing teacher concerns and uncertainties while implementing CLIL programmes, maintain that the effectiveness of CLIL depends on 'the training of teachers, student's individual characteristics, the orientation of teaching methodology, the type of curriculum chosen, the materials that are available, and also, importantly, the social context in which this [programme] occurs'. Their research shows that teachers' concerns partly stem from the fact that they may not have the necessary training to abandon the generally adopted lecturetype teacher-centred style of instruction and adopt a more communicative way to involve students who have become accustomed to being the recipients rather than active seekers of information in the subject. Wolff and Marsh (2009: 18) suggest that "a CLIL teacher undoubtedly needs a specific training that goes beyond the formation of a foreign language teacher or a subject teacher". Teachers also worry about who should be teaching a CLIL course and whether the aim of the course is fostering language competence or subject knowledge. If both aims need to be met, how can curriculum design support reaching the goal (cf. Mehisto et al. 2008, Dafouz, Guerrini 2009, Pavón, Rubio 2010)? Related to that is the concern about the prerequisite language competence of the subject teachers and respective content knowledge of the language teachers to successfully implement the course (cf. Ball et al. 2015, Pokrivčáková et al. 2015).

An important variable determining the success of a CLIL course is the availability and nature of the materials used to deliver the course. There is overwhelming agreement in research literature (Mehisto 2012, Gondová 2015, Ball et al. 2015) that despite the rapid spread of CLIL programmes 'the lack of appropriate teaching materials, both for globalised curricula and for bilingual teaching in general, constitutes one of the great challenges teachers face' (Dafous, Guerrini 2009: 25).Thus any teacher in a CLIL programme inevitably needs to engage in the development of materials to suit the needs of the particular learning context. The task is aggravated by two important variables: the quality requirement for such materials and the time available for a practicing teacher. The most comprehensive list to date of the quality criteria for CLIL materials has been provided by Mehisto (2012: 17-25):

- make the learning intentions (language, content, learning skills) and process visible to students;

- systematically foster academic language proficiency;

- foster the development of learning skills and learner autonomy;

- include self, peer and other types of formative assessment;

- help create a safe learning environment;

- seek ways of incorporating authentic language and authentic language use,

- foster critical thinking;

- foster cognitive fluency through scaffolding of content, language and the development of learning skills.

Materials designed following the above criteria help students to reach well beyond what they could do on their own, and make learning meaningful. With regard to the time issue, Ball et al. (2015: 172) maintain that 'any teacher, experienced or 
inexperienced, managing a 20-hour-plus weekly timetable with its attendant preparation and marking demands, administrative duties, and possible responsibility as a class tutor, will justifiably look upon the need to create a custom-built course for the academic year as one demand too many'.

A salient set of teacher concerns is related to assessment and evaluation in CLIL because it plays such an essential role in the learning process. As Coyle et al. (2010: 112) note, 'no matter what is taught and how it is taught, the mode of assessment shapes how the learners perceive the teacher's intention and, of course, shapes performance data'. Designing a valid, reliable and practical assessment instrument with a desired washback effect is complicated in any context, and in many cases, teacher training programmes do not incorporate assessment instrument design (Ball et al. 2015: 210). In the CLIL dual-focus context, conducting formative and summative assessment creates additional questions. Coyle et al. (2010: 114) have identified the main areas of concern here: if teachers should assess content or language or both; what the language of assessment should be; what tools can be used for assessment; how to assess previous knowledge and/or progress; how to deal with learning difficulties; provided the assessment is in English, how to minimise the effect of the language in the content assessment; how to evaluate skills and processes (i.e. planning, investigation, designing a work of art, reaching conclusions); how to assess group work.

Thus the list of teacher concerns is long and can be closely related to teacher education or rather the lack of it where CLIL is concerned. Respective research highlights problems with the quality of training and lack of teacher motivation (e.g. Lasagabaster 2010, Mehisto 2008, 2012, Marsh 2009, Pavón, Rubio 2010), underlining the lack of trained teachers to teach a subject through English or another foreign language in spite of the perceived need to promote the CLIL approach (Lasagabaster, Sierra 2009: 369).

\section{Method and respondents}

Guided by the set of areas of concern found in research literature that might adversely affect incorporating CLIL methodology in the educational system, a survey was designed to investigate the respective teacher perceptions in Estonia. The research focus was primarily on teacher attitudes, awareness, and understanding of CLIL as an approach and its usefulness in the Estonian context. As the aim was to discover the perspectives of both subject and language teachers, both populations were included. Because the study preceded a proposed launch of a CLIL geography curriculum in English in a primary school in Estonia, and information was required with respect to its development and potential instructor-related problems, a decision was made to involve teachers of English and geography in both Estonian- and Russian-medium schools here. The decision was further substantiated by the fact that geography has been one of the most frequently chosen subjects for CLIL programs as stated above. Both groups of teachers were invited to complete a survey anonymously online: the English language teachers filled in the questionnaires in English (cf. Questionnaire 1), and the questionnaires for geography teachers were conducted in Estonian (cf. Questionnaire 2a) and Russian (cf. Questionnaire 2b). 
The questionnaire for English teachers contained 20 questions and the one for the geography teachers had 9 questions: 2 questions measuring independent variables such as age and the length of teaching experience and the remaining questions concerning the attitudes towards various aspects of the CLIL approach. The number of questions in the two questionnaires varied because the language teachers' concerns related to embarking on subject-teaching seemed to be more varied than when teaching the subject in a foreign language, thus more angles seemed relevant while querying (cf. Questionnaire 1 and 2a, 2b). The CLIL-related questions addressed four areas: teacher motivation to implement CLIL in their own classes; level of readiness to teach a subject in English; views on combining subject and language teacher education; and possible challenges related to adopting the CLIL approach. The CLIL- related section was initially designed as a set of statements with multiple choice responses, which allowed the respondent to select more than one option. Once piloted, some of the statements were turned into questions for the sake of clarity and an option to supply a comment if necessary was given based on the pilot respondents' feedback; two open-ended questions were added as well. The questionnaires were sent out twice to 450 teachers of English and distributed to the geography teachers of Estonia via the Board of the Estonian Association of Geography Teachers. Altogether 49 responses were obtained: 26 responses from English teachers and 23 responses from Geography teachers.

\section{Results and discussion}

The data were analysed both quantitatively for relative frequencies and trends, as well as qualitatively to identify and analyse dispositions and opinions about the problems and concerns related to the implementation of CLIL in primary school. Because of the small number of respondents, it was not possible to draw any age- or service- related conclusions about implementing CLIL. For the same reason, geography teachers in Estonian and Russian schools were not studied separately. Also, both school types follow the same geography curriculum in Estonia, and teacher training for English and geography teachers for both school types is identical, i.e. they were considered to be working within very similar environments. For these reasons, the above discrimination was abandoned with plans for further research.

Below, responses to the survey questions/ statements will be viewed in the order that they appeared in the survey, proceeding from the English teachers' survey and relating it to the geography teachers' respective responses when appropriate. The questions/ statements will be referred to by $\mathrm{Q}$ followed by the number (e.g. question 1 = Q1). The figures in brackets represent the number of respondents who chose a particular option.

The research set out to explore the general awareness of the approach (Q1) and, as it was assumed that there would be some but not necessarily extensive familiarity with it, if there would be motivation to know more about the approach (Q2). The responses are summarised in Figures 1 and 2. 


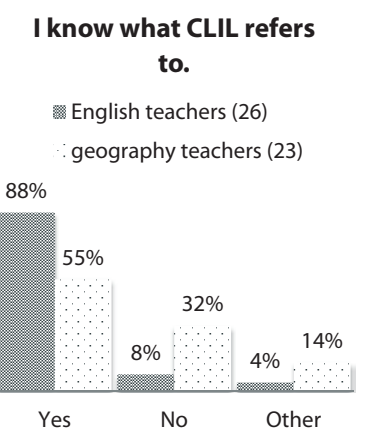

Figure 1. Familiarity with CLIL among English and geography teachers

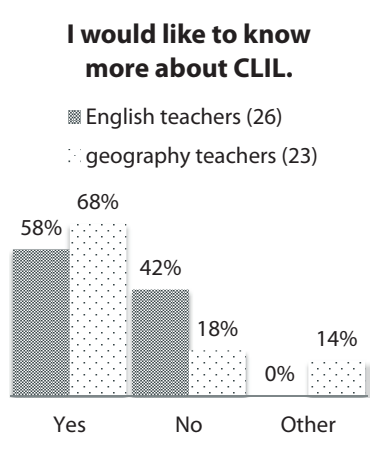

Figure 2. Interest in CLIL among English and geography teachers

As can be seen, there is a difference in how many teachers know about CLIL depending on the area they work in. Most English teacher respondents reported knowing about it (23 teachers out of 26 , i.e. $88 \%$ ), whereas only slightly more than half of the geography teachers (13 out of 23, i.e. $55 \%$ ) know about it. This probably also explains why the number of those who would like to learn about the approach is larger among the geography teachers (16 of 23, i.e. 68\%) than among English teachers (15 of 26 , i.e. $58 \%$ ).

The next query (Q3) was related to how interested teachers were in implementing CLIL in their own classroom practices. The responses are recorded in Figure 3.

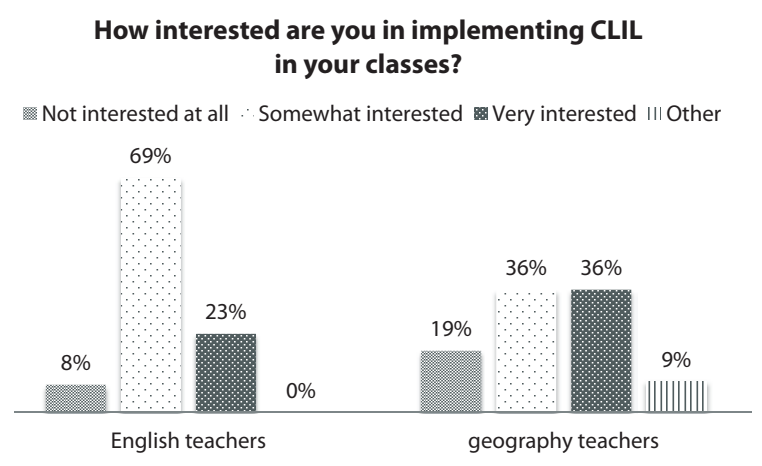

Figure 3. Teacher motivation to implement CLIL in own teaching

It is noticeable that more teachers in both groups are either not interested in implementing CLIL in their classroom at all (3 English teachers - 8\% and 5 geography teachers - 19\%) or are just somewhat interested in doing so (18 English teachers $-69 \%$ and 8 geography teachers $-36 \%)$. The overall teacher reluctance may be related to the already very substantial workload of teaching their own subject and the perceived additional challenges related to adopting a new approach. It is encouraging, though that 6 of the 26 English teacher respondents (23\% of those answering) and 8 of the 23 geography teachers (36\%) were very interested in using the approach. It is difficult to speculate about the reasons for the interest without knowledge of a particular context. The interest might be a reflection of their generally 
positive attitude to innovative teaching methodologies, but it might also be an indication of the changing demographic situation in the classroom and thus a need for a different approach; alternatively, it might derive from the parents requesting a more international (i.e. prestigious) approach to education (cf. Ball et al. 2015: 10). Geography teachers' relative reluctance might be partially accounted for by their generally lower awareness of the content of the concept.

The following question (Q4) attempted to discover what the teachers' perspective of the CLIL purpose was. Options were provided to the respondents as seen in Figure 4 below, which also summarises the answers to that question. The teachers could check several boxes.

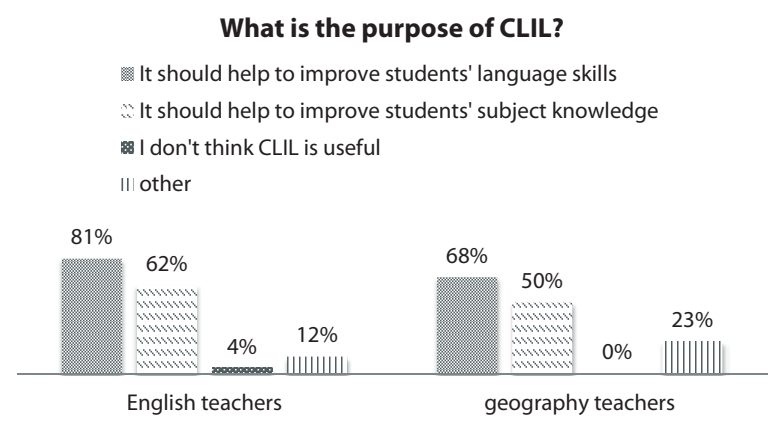

Figure 4. Teachers' perspective on the purpose of CLIL

In general, the teachers seem to suggest that CLIL mostly serves the purpose of language development: 22 English teachers and 16 geography teachers noted that. Subject knowledge improvement in the teachers' experience is secondary (16 English teachers and 12 geography teachers) in importance. There was one English teacher who maintained that CLIL was not useful without providing a reason, but 3 English teacher respondents and 5 geography teachers noted 'other' as their choice, which may also suggest that they are sceptical of the usefulness of the approach. As no comments were provided by the respondents themselves, however, this remains speculatory.

As the survey was a precursor to launching a CLIL curriculum, one of the important queries was if English teachers in general were willing to engage in CLIL (Q5) and if so, propose concrete fields they would like to engage in (Q6). The responses are recorded in Figures 5 and 6.

As seen in Figure 5, the English teachers' responses were fairly evenly divided between 'yes' and 'no', with slightly more affirmative responses. No reasons were indicated either by those who declined taking up another subject or the three people who did not indicate a clear preference. The subject areas that the respondents could choose from were those on the current primary school curriculum that could feasibly be taught either partly or completely in English. The most frequently chosen subject was quite predictably literature, as it is part of most English teachers' BA programme, so they are more confident to teach its content. The next most popular choices were geography (6) and biology (4), followed by art, music and handicrafts in equal measure (3) and finally math and physical Education (2). English teachers are the least confident in teaching chemistry and physics, probably because of the perceived conceptual distance of those subjects from their current field. 


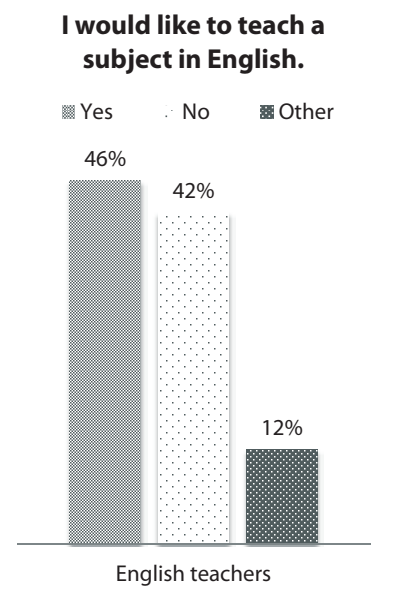

Figure 5. English teachers' willingness to teach a subject other than language

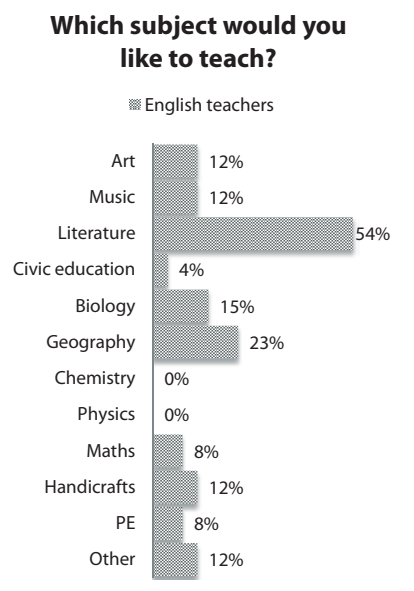

Figure 6. Other subjects English teachers would teach

If undertaken, the respondents probably feared the substantial increase in workload that would stem from having to acquire large amounts of subject-specific content knowledge as well as methodology.

The next survey question (Q7) delved into teachers' CLIL-related concerns. Some of the challenges were indicated as multiple-choice options but the item also offered an open-ended alternative to allow teachers to voice their own concerns (cf. Figure 7).

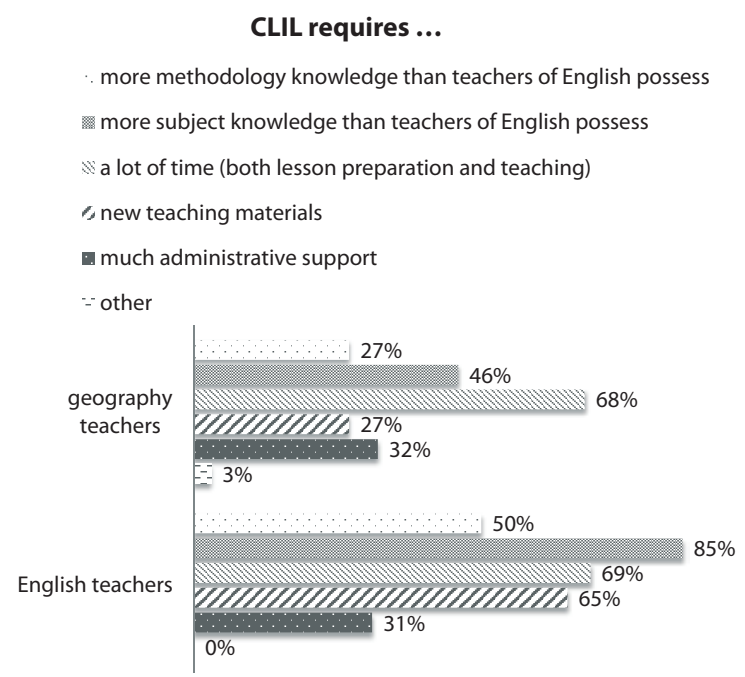

Figure 7. Teachers' perceived CLIL-related challenges

Both respondent groups are concerned in equal measure about the time required to pursue CLIL. Quite predictably, fewer subject teachers than English teachers are concerned about the level of subject specific knowledge (22 English teachers 
out of 26 indicated the need for more subject knowledge - their overwhelmingly biggest concern). It must be observed that English teachers are also noticeably more concerned than geography teachers about methodological support and the provision of teaching materials to teach a subject in English. This may be because there is greater awareness of these issues among English teachers who may have had some experience of teaching elements of particular subjects within an English course, while teaching a subject completely in English by a subject teacher has not been widely practiced here at all. An important concern noted by a third of both groups is the need for administrative support. Although clarifications were not provided by the respondents, the teachers adopting a CLIL approach would certainly need curricular, timetabling, temporal, financial and moral support to succeed.

Part of the CLIL-related discussion is determining what the students' level of English should be to participate (Q8). Figure 8 summarises the teachers' views in this regard.

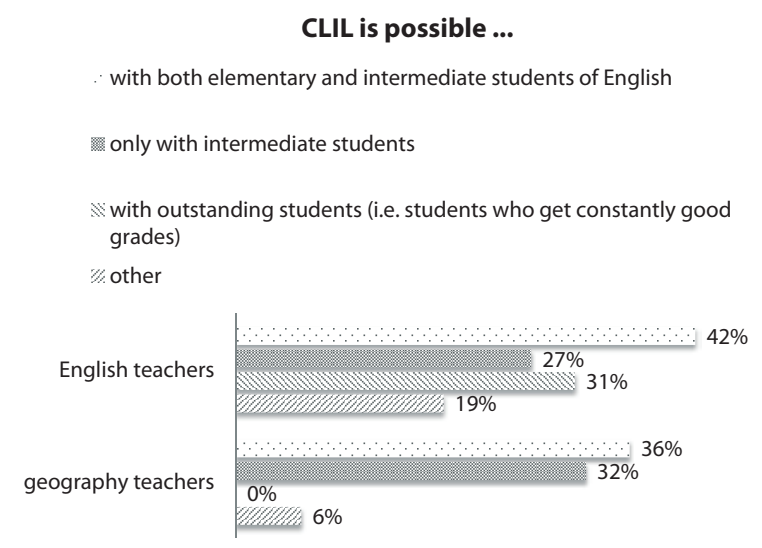

Figure 8. Level of students in CLIL

Because Estonian primary school students rarely reach the advanced level in English, only elementary and intermediate options were included in the survey. The opinions are fairly mixed here. About half of English teachers (11 respondents) and a third of geography teachers ( 8 respondents) believe that CLIL is possible with both elementary and intermediate students, but about a third (7 respondents) in both groups expect a higher level of English (intermediate). It is interesting to note that also about a third of the English teachers (31\%) consider good general progress a prerequisite for CLIL while none of the geography teachers find it necessary. Six people (5 English teachers and 1 geography teacher) have indicated that the level should be other than the options offered. Because of the lack of specification, it can only be supposed that they may consider the language level irrelevant or that they deem only advanced students ready for CLIL.

English teachers were further questioned about their experience with subject teaching in English either independently (Q9) or as an assistant to a subject teacher (Q10). The responses are represented in Figures 9 and 10. 


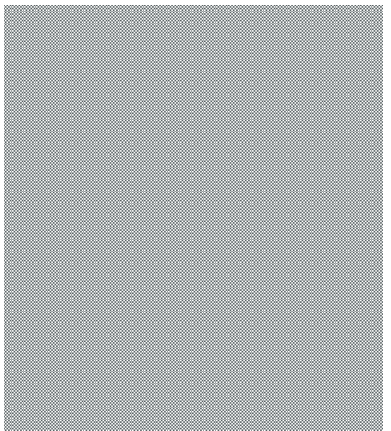

Figure 9. Subject teaching experience of English teachers

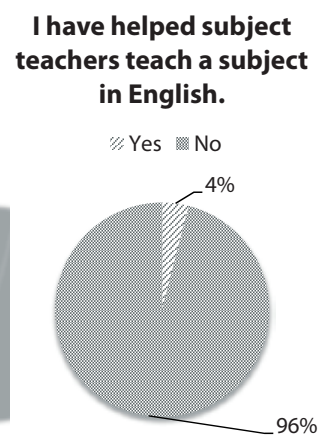

Figure 10. English teachers assisting subject teachers

Figure 9 shows that English teachers have relatively little experience of teaching a subject in English; just 5 people report having done that. On the other hand, there is a curiously notable number of respondents who have indicated 'other' as the response. This may reflect the fact that English teachers have included elements of subject teaching in their English course and thus have not taught a full course but just a part of it. The practice of a subject teacher and an English language teacher working together to teach a subject seems to be very rare according to the current survey, only one English teacher respondent having assisted a subject teacher (Figure 10).

The survey respondents are fairly certain about the positive impact and usefulness of CLIL (cf. Figures 11 and 12), with 41 out of 49 respondents testifying to it.

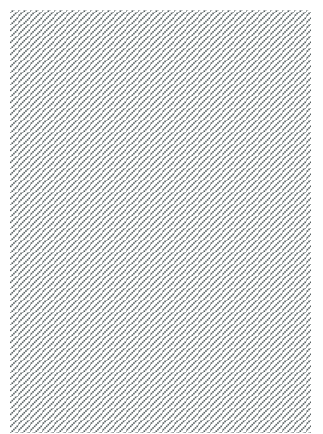

Figure 11. General usefulness of CLIL as expressed by English teachers

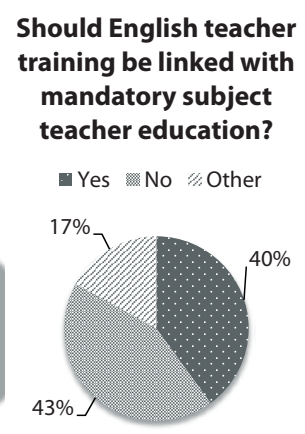

Figure 12. Specific usefulness of CLIL

When asked, if the CLIL approach mostly benefitted subject or language development, two thirds of the English teachers (17) considered CLIL to have an integrated benefit serving both purposes. Also, there were two fairly equal groups maintaining that CLIL has a discrete effect on either language (8) or subject development only (7).

With the proposed curriculum in the given context designed to engage English teachers in subject teaching, English teachers were invited to comment on their need for additional subject teacher training, and furthermore, if English teacher training in general should be linked with mandatory subject teacher education (cf. Figures 13 and 14). 


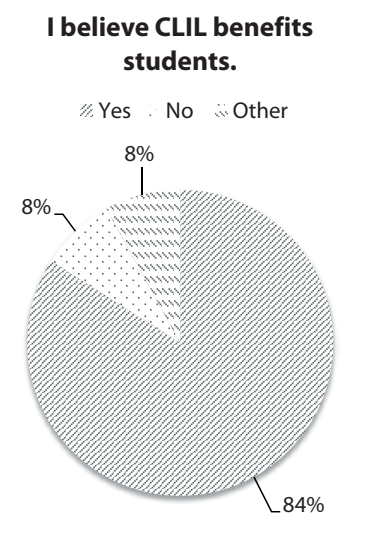

Figure 13. Perceived need of subject training expressed by English teachers

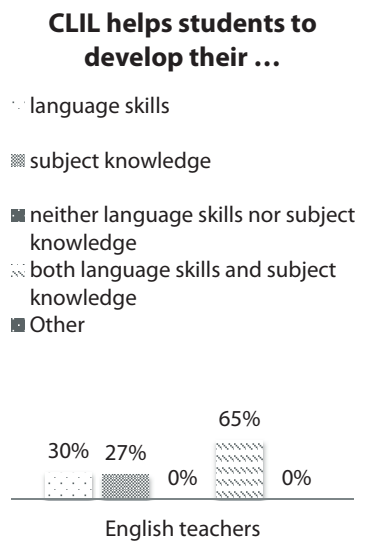

Figure 14. Need to link language and subject teaching according to English teachers

Quite predictably, most English teachers (19) report needing additional subject training to be able to teach a particular subject curriculum. As to mandatory subject teacher education, the respondents seemed to be almost equally divided between those who support it (10) and those who do not (11). Teacher comments with regard to CLIL related in-service training or self-education labelled it "extremely time-consuming" (19), at the same time occasionally affirming the usefulness of mandatory subject teacher education for English teachers: "every prospective teacher could learn to teach at least two subjects at the university" (8). Thus there is some interest in pursuing knowledge and experience about combining language and subject teaching. Further research is needed, however, to investigate the full extent of such interest among teachers as well as what might motivate them to actively engage in the respective training and teaching practices.

In addition to the need for additional subject training, respondents were also requested to comment on their own perception of their level of English and whether it was good enough to teach a subject in English (cf. Figures 15 and 16).

How would you define your level of English?

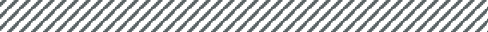

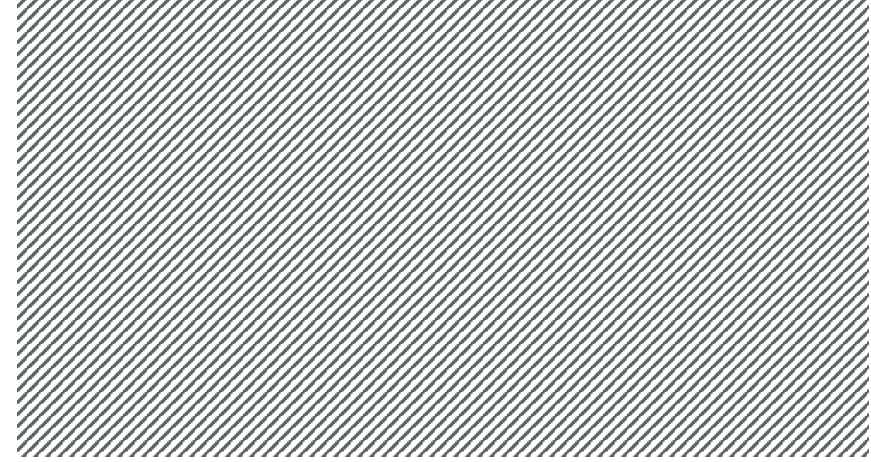

Figure 15. Perceived language proficiency level 


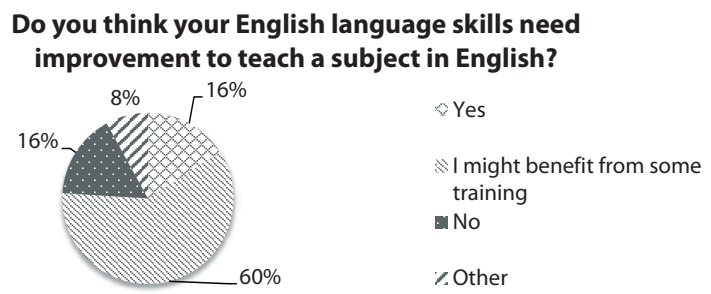

Figure 16. Perceived need to improve language ability

The majority of English teachers (15) estimated their level at $\mathrm{C} 1$ on the Common European Framework of Reference (CEFR) scale, with 3 ranking themselves at B2 and 4 at C2. The same amount of people (4) labelled their level satisfactory without specifying what it meant. Most geography (11) teachers noted that their English language level was B1, but many noted that their English does not go beyond A level (5 people at A1 and 5 people at A2), which allows the language user to 'communicate in simple and routine tasks requiring a simple and direct exchange of information on familiar and routine matters, [---] describe in simple terms aspects of his/her background, immediate environment and matters in areas of immediate need' (CEFR) and makes teaching in a foreign language problematic at best. The survey thus shows that from the perspective of general language ability, language teachers are clearly more prepared to manage CLIL lessons than content subject teachers, yet they often lack specific topic knowledge and terminology to manage a specialist subject course. Still, the majority of the respondents (29) admit that they would benefit from some training on specific aspects of English.

The final two open-ended survey questions explored the respondents' perceptions of the benefits and problems of the CLIL approach. The most frequently mentioned benefits were the improvement of students' general language ability (15) and communication skills (9), indicating that they saw CLIL as a language improvement vehicle. As drawbacks, the teachers noted lack of resources (7) and the need to design materials themselves (8). There was also commentary with respect to awareness of the existing CLIL tradition in Estonia, or at least elements of it, which found vent in statements like: "CLIL has been practiced in several Estonian schools since the 1960s. There is no need to re-invent the wheel". Reluctance to incorporate CLIL through the medium of English was voiced in fairly strong terms by teachers working in Russian-medium schools, which already rely heavily on CLIL via the Estonian language: "in Russian [medium] schools in Estonia CLIL is impossible because a lot of time is taken by the subjects in the Estonian language and there is no time for English", probably suggesting that in addition to the temporal constraints set by adopting English to teach particular subjects, there would also be noticeable cognitive strain on the students who would face the challenge of studying some subjects in L1, others in foreign language 1 and yet others in foreign language 2. 


\section{Conclusion and implications}

Content and language integrated learning using English as a medium of instruction is not a new phenomenon in the Estonian educational landscape, but it has been mostly confined to a few select schools and, with a few exceptions, is generally designed to serve the purpose of promoting students' English language proficiency.

The current small-scale study shows quite predictably that English teachers are noticeably more aware of the nature and potential of the CLIL approach with its attendant challenges than are subject teachers. Although most of the English teacher respondents in the study had not taught a full CLIL course, they indicate having incorporated elements of subject teaching into language teaching.

Considerably more subject teachers than language teachers expressed a wish to expand their knowledge of CLIL-related topics. In the situation where most teachers view CLIL as a language development vehicle, this was a somewhat surprising, yet a welcome outcome. By encouraging integrated subject and language teaching practices, the national curriculum goals concerning learning to learn and communication competencies (cf. National Curriculum) could be more readily met.

Yet, in spite of the general interest in the CLIL approach, there was reluctance among the respondents to incorporate it in their own classrooms. This was generally related to the already mentioned widespread belief that the approach benefits the development of language skills rather than subject knowledge and thus marginalises the latter, undermining overall achievement of curricular goals. Coupled with the English teachers' admitted lack of subject-specific content knowledge, the subject teachers' generally low estimate of their English language proficiency, the perceived lack of appropriate teaching materials and the temporal concerns related to developing a new course with attendant materials development responsibilities, the teachers' apprehensions seem somewhat justified.

It is noteworthy that many concerns voiced in the respective research literature, e.g. curriculum design, problems of assessment and evaluation, quality criteria for teaching materials, ways of combining language and subject development, etc., were not found in the current survey's teacher commentary. This is probably because of the lack of field knowledge and experience of all the aspects related to conducting a full-fledged CLIL course among most respondents. Given the teachers' interest in the CLIL approach and the fact that the educational context in Estonia is changing in line with the demographic changes taking place all over Europe, there is a clear need for both initial and in-service teacher training to prepare teachers to apply CLIL to deal with the aforementioned challenges. The teacher education programmes that allow combining language and subject teacher training set up by the universities here are a step in the direction of closing this gap, but different types of in-service professional development options should also be available for both language and subject teachers. Further training is similarly needed for members of local governments responsible for schools as well as school managers to alert them to the administrative and motivational aspects of applying CLIL in Estonian schools.

The current study is limited in terms of its generalisability because of the small number of respondents. The low rate of participation does not allow for age-, gender-, or proficiency-related conclusions with regard to the CLIL approach in the classroom. Also, it would be useful to investigate if teacher attitudes vary 
depending on whether they teach in Estonian- or Russian-medium schools, in spite of the seemingly very similar environment they are teaching in. A follow-up study thus seems in order which would focus more meticulously on the aforementioned aspects with the help of a carefully-constructed research tool.

In spite of their limitations, the findings of the present study are useful in that they inform teacher education about the features of the CLIL teaching/learning contexts where English is the lingua franca, which has not yet been widely researched in Estonia. Also, with the increase of the number of immigrant students in the Estonian classrooms, it is likely that the CLIL approach will be utilised through the medium of Estonian in addition to English. From this point of view the challenges of the CLIL approach viewed above have relevance in a wider context.

\section{References}

Ball, Phil; Kelly, Keith; Clegg, John 2015. Putting CLIL into Practice. Oxford: Oxford University Press.

CEFR = Common European Framework of Reference for Languages: Learning, Teaching, Assessment. Cambridge: Cambridge University Press, 2001.

Coyle, Do 2007. Content and language integrated learning: towards a connected research agenda for CLIL Pedagogies. - The International Journal of Bilingual Education and Bilingualism, 10 (5), 543-562. https://doi.org/10.2167/beb459.0

Coyle, Do; Hood, Philip; Marsh, David 2010. CLIL: Content and Language Integrated Learning. Cambridge: Cambridge University Press

Dafouz, Emma; Guerrini, Michele 2009. CLIL across Educational Levels. Richmond Publishing.

Dalton-Puffer, Christiane; Nikula, Tarja (Eds.) 2015. Language Learning Journal, 43 (3). Special Issue: Content and Language Integrated Learning II. http://www.tandfonline. com/toc/rllj20/43/3 (29.3.2018).

Darn, Steve 2015. Content and Language Integrated Learning (CLIL): A European Overview. Working paper. ERIC document reproduction service no. ED490775. The Education Resources Information Center.

Deller, Sheelagh; Price, Christine 2007. Teaching Other Subjects through English. Oxford: Oxford University Press.

Frigols, María Jesús; Marsh, David; Mehisto, Peeter; Wolff, Dieter 2011. European Framework for CLIL Teacher Education a Framework for the Professional Development of CLIL Teachers. Graz: European Centre for Modern Languages.

Genesee, Fred; Hamayan, Else 2016. CLIL in Context. Practical Guidance for Educators. Cambridge: Cambridge University Press.

Gerdes, Teresa; Pavón, Víctor 2008. Talking CLIL. http://www.academia.edu/9168371/ (29.3.2018).

Gondová, Danica 2015. Selecting, adapting and creating CLIL materials. - S. Pokrivčáková et al., CLIL in Foreign Language Education: E-Textbook for Foreign Language Teachers. Nitra: Constantine the Philosopher University, 153-163. https://doi.org/10.17846/ CLIL.2015.153-163

HaridusSilm. http://www.haridussilm.ee/ (29.3.2018).

Hurajová, Ludmila; Luprichová, Jana 2015. Being a CLIL teacher. - S. Pokrivčáková et al., CLIL in Foreign Language Education: E-Textbook for Foreign Language Teachers. Nitra: Constantine the Philosopher University, 99-111. https://doi.org/10.17846/ CLIL.2015.99-111

Johnson, Robert Keith 1997. Immersion Education: International Perspectives. Cambridge: Cambridge University Press. https://doi.org/10.1017/CBO9781139524667 
Lasagabaster, David 2010. CLIL in Spain Implementation, Results and Teacher Training. Newcastle: Cambridge Scholars.

Lasagabaster, David; Sierra, Juan Manuel 2009. Immersion and CLIL in English: more differences than similarities. - ELT Journal, 64 (4), 367-375. https://doi.org/10.1093/ elt/ccpo82

Lin, Angel Mei Yi 2016. Language across the Curriculum \& CLIL in English as an Additional Language (EAL) Contexts. Theory and Practice. Springer. https://doi. org/10.1007/978-981-10-1802-2

Maljers, Anne; Marsh, David; Wolff, Dieter (Eds.) 2007. Windows on CLIL: Content and Language Integrated Learning in European Spotlight. Hague, Alkmaar: European Platform for Dutch Education.

Marsh, David 2009. Foreword. - Ruiz De Zarobe Yolanda, Rosa María Jiménez Catalán (Eds.), Content and Language Integrated Learning: Evidence from Research in Europe. Bristol, UK: Channel View Publications, vii-viii.

Mehisto, Peeter 2008. CLIL counterweights: recognising and decreasing disjuncture in CLIL. - International CLIL Research Journal, 1 (1), 93-119.

Mehisto Peeter, 2012. Criteria for producing CLIL learning material. - Encuentro, 21, 15-33.

Mehisto, Peeter; Marsh, David; Frigols, María Jesús 2008. Uncovering CLIL: Content and Language Integrated Learning in Bilingual and Multilingual Education. Oxford: Macmillan Education.

National Curriculum for Upper Secondary Schools. https://www.riigiteataja.ee/en/ eli/524092014009/consolide

Nikula, Tarja 2016. CLIL: A European approach to bilingual education. - N. V. Deusen-Scholl, S. May (Eds.), Second and Foreign Language Education. Springer International Publishing, 1-14. https://doi.org/10.1007/978-3-319-02323-6 10-1

Pavesi, Maria; Bertocchi, Daniela; Hofmanová, Marie; Kazianka, Monika 2001. Insegnare in una lingua straniera. Milan: M.I.U.R..

Pavón Victor; Rubio, Fernando 2010. Teachers' concerns and uncertainties about the introduction of CLIL programmes. - Porta Linguarum, 14, 45-58.

Pokrivčáková, Silvia; Babocká, Mária; Bereczky, Klára; Bodorík, Michal; Bozdoğan, Derya; Dombeva, Lyubov; Froldová, Vladimíra; Gondová, Danica; Hanesová, Dana; Hurajová, Ludmila; Leung, Patrick; Luprichová, Jana; Sepešiová, Michaela; Straková, Zuzana; Šimonová, Ivana; Trníková, Jana; Xerri, Daniel; Zavalarit, Konstantina 2015. CLIL in Foreign Language Education: E-Textbook for Foreign Language Teachers. Nitra: Constantine the Philosopher University.

Questionnaire 1. Questionnaire for English Teachers. https://docs.google.com/forms/ d/e/1FAIpQLSeyP1BIEJ5yzsT6vIaIMCzS1edcDHyOWZl3fPGQpzVlaKQAkA/viewform? $\mathrm{c}=0 \& w=1$ (29.3.2018).

Questionnaire 2a. Questionnaire for Geography Teachers (in Estonian). https://mail.google. com/mail/u/o/\#inbox/160e55e6cffed449 (29.3.2018).

Questionnaire 2b. Questionnaire for Geography Teachers (in Russian). https://mail.google. $\mathrm{com} / \mathrm{mail} / \mathrm{u} / \mathrm{o} / \#$ inbox/160e55f22684ec7d (29.3.2018).

Stryker, Stephen; Leaver, Betty Lou 1993. Content-Based Instruction in Foreign Language Education. Washington, D.C.: Georgetown University Press.

Tallinna Inglise Kolledž. https://tik.edu.ee/p/253-ib-tallinna-inglise-kolledzis (29.3.2018).

Tampere, Kaire 2010. Content and Language Integrated Learning: Estonian CLIL Teacher Profile. Lambert Academic Publishing.

Wolff, Dieter; Marsh, David 2007. Diverse Contexts, Converging Goals: CLIL in Europe. Frankfurt: Peter Lang. http://dx.doi.org/10.3726/978-3-653-01429-7 


\title{
LÕIMITUd AINE- JA KEELEÕPPE (LAK) RAKENDAMISE YÕIMALIKKUSEST AINE- JA KEELEÕPETAJA VAATENURGAST
}

\author{
Anna Dvorjaninova, Ene Alas
}

Tallinna Ülikool

Artikkel kajastab keeleõpetajate ja aineõpetajate murekohti kaardistanud uurimust, mis vaatles lõimitud aine- ja keeleõppe (LAK) kui metoodika võimalikku kasutamist ainetunnis, kus õppekeeleks on inglise keel. Ankeetuuringus osalenud inglise keele ja geograafia õpetajad suhtusid võimalikku LAK-õppe rakendamisse oma praktikas kahtlevalt. Põhjuseks on laialt levinud arvamus, et LAK-metoodika teenib pigem keeleõppe kui aineteadmiste edendamist viimast marginaliseerides ning seega õppekava eesmärkide saavutamist takistades. Kui lisada inglise keele õpetajate nimetatud piiratud ainetundmine ja aineõpetajate hindamine oma inglise keele oskus madalaks, vastavate õppematerjalide vähesus ning vähene ajaressurss, mis oleks vajalik uue kursuse ja selleks vajalike materjalide väljatöötamiseks, siis tundub LAK-õppe rakendamine paljudele märkimisväärse katsumusena.

Võtmesõnad: keeleõpe, keeleomandamine, LAK-õpe, aine- ja keeleõpetaja taju, õppekava arendus, keelepädevus, aineõpe

\footnotetext{
Anna Dvorjaninova on inglise keele õpetaja Tallinna Pae Gümnaasiumis. Ümera 14-27, 13817 Tallinn, Estonia a.dvorjaninova@pae.tln.edu.ee
}

Ene Alase (Tallinna Ülikool) teadushuvid on keeletestimine, testide koostamine ja nende kvaliteedi hindamine, õpetajakoolitus ja õppekirjanduse hindamine. Narva mnt 25, 10120 Tallinn, Estonia enealas@tlu.ee 